JeMAS 15 (1) (2019) 29-38
Jitt://journal.unnes.ac.id/nju/index.php/kemas

\title{
Predisposing, Enabling and Reinforcing Factors of Premarital Sex Behavior in School Adolescents
}

\author{
Suci Musvita Ayu $^{1 凶}{ }^{\circledR}$, Liena Sofiana ${ }^{1}$, Marsiana Wibowo $^{1}$, Erni Gustina ${ }^{1}$, Arie Setiawan $^{1}$ \\ ${ }^{1}$ Public Health Study Program, Faculty of Public Health, Ahmad Dahlan University, Indonesia
}

\section{Article Info}

Article History:

Submitted April 2018

Accepted March 2019

Published July 2019

\section{Keywords:}

The premarital sexual

behavior, adolescents

DOI

https://doi.org/10.15294/

kemas.v15i1.14226

\begin{abstract}
Nowadays, $60 \%$ adolescents in Indonesia admitted that had practiced premarital sex behavior and $50 \%$ of people living with HIV and AIDS are adolescent age group. The negative consequences of sex behavior which causes an Indonesian adolescent disrupted opportunities continue study at school, enter the work force, starting become a family and become a member of society as well. Premarital intercourse makes unintended pregnancy rates still high. Based on data obtained from the Pekanbaru City HIV-AIDS Management Commission (KPA) in April 2017, it was found that HIV-AIDS cases have always increased from year to year. The purpose of this study was to determine the correlation between predisposing, enabling, and reinforcing factors with premarital sex behavior in adolescents. The design was cross sectional study. This study was conducted August 2017 with multistage random cluster sampling and with 481 adolescent respondents in 18 SMA in Yogyakarta City, which were analyzed using Chi Square test. There were a relationship of knowledge $(\mathrm{p}=0.000, \mathrm{RP}=3.893)$, attitude $(\mathrm{p}=0.000, \mathrm{RP}$ $=7.240)$, self-esteem $(p=0.000, R P=3.502)$, source of information $(p=0.003)$ and peer roles $(\mathrm{p}=0.000, \mathrm{RP}=11.660)$ with premarital sex behavior. Meanwhile, there were no relation of family role $(\mathrm{p}=0.436, \mathrm{RP}=0.823)$ and teacher role $(\mathrm{p}=0.053 \mathrm{RP}=1.596)$ with premarital sex behavior. Knowledge, attitudes, self-esteem, information source and the role of peers are related to premarital sex behavior. The role of the family and the role of the teacher are not related to premarital sex in adolescents.
\end{abstract}

\section{Introduction}

Adolescence is one of important phases for development in the later stages of life (Azinar, 2013). Based on the population census in 2000, the number of adolescents in Indonesia is 62.594 .200 people or around $30.41 \%$ of the total population of Indonesia. Unhealthy sexual behavior among adolescents, especially unmarried ones tend to increase (Badan Pusat Statistik, 2005). This is evident from the results of several studies that show the age of adolescents when they had first engage in active sexual intercourse varies between ages 14-23 years with peak age is between 15-18 years (Harries, Paglia, Redden, \& Grant, 2018). Adolescents (10-24 years) need serious concern because they are included in school age and working age, it is prone to reproductive health problems, such as premarital sexual behavior, smoking, alcohol and drug abuse (BKKBN, 2011).

The causes behind of free sex behavior are incredibly diverse. Sexuality problems in adolescents due to hormonal changes increase sexual desire. The change in attitudes and behaviors during adolescence is parallel to physical changes. Premarital sex behavior seems to be one of the biggest problems in various

\footnotetext{
Correspondence Address:

Department of Public Health Science, Universitas Ahmad dahlan, Indonesia.

Email : suci.ayu@ikm.uad.ac.id 
cases of juvenile delinquency. Cases from year to year show an increase in premarital sex incidents among adolescents. Sexual behaviors that happened are not accompanied by adequate knowledge in adolescents. The phenomenon can be induced by environmental influences, social culture, religious appreciation, the application of values, psychological factors to economic factors. Based on research journals and related references, several factors that influence free sex are both external and internal, such as family background, reference or peer group, biological changes, sexual experience, mass media, lack of knowledge about reproductive health, the level of cognitive and moral development, age, history of domestic violence, increased promiscuity, narcotics, alcohol, psychotropic and addictive substances (drugs) abuse, poverty, residence status, religiosity, and personality or self-identity (Bendas, 2018).

In Indonesia, $63 \%$ of adolescents have had sexual contact with the opposite sex and $21 \%$ have had an abortion. As many as $93.7 \%$ of middle and high school adolescents ever had kissed, genital stimulation (fingering genitals) and oral sex, meanwhile $62.7 \%$ of junior high school adolescents were not virgins, and lastly $21.2 \%$ of adolescents claimed to have had abortions. Unhealthy sexual behaviors among adolescents tend to increase. About $1 \%$ of girls aged 15 to 24 years have had sexual intercourse before marriage. Whereas, the teenage boys who do the same thing are higher (2.6\%). The results of the reproductive health survey of adolescents, Indonesian adolescents are first dating at the age of 12 years. Adolescent dating behavior was also increasingly permissive, with $92 \%$ of adolescents holding hands during dating, $82 \%$ kissing, and $63 \%$ dealing with petting. These behaviors could then trigger the adolescents to have sexual intercourse with his/ her partner (Suparmi dan Isfandari, 2016).

Pre-marital sexual intercourse in adolescents results in higher rates of unwanted pregnancies. This is because almost all adolescents who have had sex do it without contraception at all. Besides that, unwanted pregnancies in adolescents often end in abortion. Medical risks of abortion in adolescents are quite high, such as bleeding, complications due to unsafe abortion, and death. Adolescents' knowledge about sex is still very lacking. This factor is coupled with inaccurate information obtained from wrong sources, such as myths about sex, pornographic VCDs, pornographic sites on the internet and others that will make their understanding and perception of sex mistaken. Knowledge of adolescents who do not know about premarital sexual behavior, it is possible to make them misbehave and then have behaviors towards sexuality. In addition to these influencing factors, adolescents have a perception that sex is a way of expressing love, so for the sake of love, someone have sexual intercourse with his/her loved one before marriage (Nugroho, et. al. 2017)

Other data show that pre-marital sex in East Java, Central Java, West Java and Lampung: $0.4-5 \%$ in Surabaya, 2.3\% in West Java: 1.3\% in urban area and $1.4 \%$ in rural area. In Bali: $4.4 \%$ in urban area, while in rural is $0 \%$. But several other studies found a far more fantastic number; $21-30 \%$ of Indonesian adolescents in big cities like Bandung, Jakarta, and Yogyakarta ever had pre-marital sex. Some of the students revealed, he had sex based on love and without coercion (Darmasih, 2009).

High school adolescents in Surakarta, in the study that has been conducted have results where knowledge is related to premarital sex behavior $(p$-value $=0.022<0.05)($ Darmasih, 2009). Related to the many occurrences of sexual behavior among adolescents lately, we are interested in examining these problems. Based on these matters, there are many factors that influence the occurrence of premarital sexual behavior among adolescents such as knowledge, attitudes, self-confidence, source of information, family roles, teacher roles and peer roles with premarital sexual behavior in adolescent schools in the city of Yogyakarta.

\section{Method}

This study was an observational study using a quantitative approach with a cross sectional design. The population in this study was all students in 80 high schools in Yogyakarta in the amount of 36.360 students. The sampling technique used a multistage random cluster sampling. The sampling was based on the calculation of sample size and $10 \%$ addition to avoid missing data. Sampling was also based on certain criteria, namely the 
inclusion criteria: all students aged 15-19 years old, schools selected as study location based on sampling technique and students who are willing to become respondents. Exclusion criteria: the number of students was less than the minimum number of samples per school that needed and sub-districts that have less than 3 (three) villages.

The sample size was taken as many as 481 students. The instrument in this study was a questionnaire. Data were analyzed using Chi Square analysis.

\section{Results and Discussion}

Characteristics of respondents are presented in the distribution table of respondents based on age, sex and level of education of parents.

Based on Table 1, we found that the most of the respondents were ages 16 years old, which were 231 people (48\%). Based on sex distribution, there were 245 male respondents (50.9\%). The highest percentage of education level for parents was high school graduate with a total of 216 people (44.9\%).

Based on Table 2, the level of knowledge of students having high knowledge amounted to 330 respondents $(68.6 \%)$. Respondents who had a positive attitude were 243 respondents (50.5\%). Respondents who had a high selfesteem amounted to 324 respondents (67.4\%). Sources of information can be in the low category with a total of 253 respondents (52.6\%). The role of the family in involvement shapes the behavior of adolescents so that they do not have premarital sexual behavior with a result of 332 respondents (69\%). The role of the teacher in involvement shapes the behavior of adolescents in order not to have premarital sexual behavior known to obtain results of 403 respondents $(83.8 \%)$. The role of peers in forming premarital sexual behavior was 261 respondents (54.3\%). There were 392 respondents who stated never had premarital sex behavior (81.5\%).

The results of the bivariate analysis illustrated in the following table conducted on the seven variables tested there are six variables that were statistically and biologically significant, namely knowledge, attitudes, selfesteem, information source, teacher roles and peer roles.

Table 1 Distribution of Characteristics of Respondents by Age, sex and Parent's Education Level

\begin{tabular}{llll}
\hline No & Characteristics & Frequency $(\mathrm{n})$ & Percentage $(\%)$ \\
\hline 1 & Age (years) & & \\
& 15 & 85 & 17.7 \\
16 & 231 & 48 \\
17 & 118 & 24.5 \\
& 41 & 8.5 \\
& 18 & 6 & 1.2 \\
& & \\
& Sex & & \\
& Male & 236 & 49.1 \\
& Female & 245 & 50.9 \\
Parents educations & & \\
& Unknown & 62 & 12.9 \\
Elementary school & 26 & 5.4 \\
Middle school & 36 & 7.5 \\
High school & 216 & 44.9 \\
University & 141 & 29.3 \\
Total & 481 & 100 \\
\hline
\end{tabular}

Source: Primary Data, 2017 
Table 2 Distribution of Characteristics of Respondents Based on Knowledge, Attitude, SelfEsteem, Information Source, the Role of Teachers, the Role of Peers and Premarital Sex Behavior

\begin{tabular}{|c|c|c|c|}
\hline No & Variable & Frequency $(\mathrm{n})$ & Percentage $(\%)$ \\
\hline \multirow[t]{3}{*}{1.} & Knowledge & & \\
\hline & Low & 151 & 31.4 \\
\hline & High & 330 & 68.6 \\
\hline \multirow[t]{3}{*}{2.} & Attitude & & \\
\hline & Negative & 238 & 49.5 \\
\hline & Positive & 243 & 50.5 \\
\hline \multirow[t]{3}{*}{3.} & Self esteem & & \\
\hline & Low & 157 & 32.6 \\
\hline & High & 324 & 67.4 \\
\hline \multirow[t]{4}{*}{4.} & Information source & & \\
\hline & Low & 253 & 52.6 \\
\hline & Moderate & 119 & 24.7 \\
\hline & High & 109 & 22.7 \\
\hline \multirow[t]{3}{*}{5.} & Family role & & \\
\hline & Low & 149 & 31 \\
\hline & High & 332 & 69 \\
\hline \multirow[t]{3}{*}{6.} & Teacher role & & \\
\hline & Low & 78 & 16.2 \\
\hline & High & 403 & 83.8 \\
\hline \multirow[t]{3}{*}{7.} & Peer role & & \\
\hline & High & 261 & 54.3 \\
\hline & Low & 220 & 45.7 \\
\hline \multirow[t]{4}{*}{8.} & Premarital sex behavior & & \\
\hline & Yes & 89 & 18.5 \\
\hline & No & 392 & 81.5 \\
\hline & TOTAL & 481 & 100 \\
\hline
\end{tabular}

Source: Primary Data, 2017

The results of the bivariate test between knowledge with premarital sex behavior showed the $p$-value $=0.000$, which means that there was a relationship between knowledge with premarital sex behavior. The result of the Ratio Prevalence (RP) was more than 1 (3.893), which means that the prevalence of premarital sexual behavior in adolescents who had low knowledge about premarital sex behavior was 3.893 times greater than the prevalence of premarital sexual behavior in adolescents who had high knowledge. This means that knowledge is a risk factor for premarital sexual behavior.

These results are in accordance with the results of previous studies that there is a significant relationship between knowledge of premarital sexual behavior of adolescents ( $p=$ 0,000) (Umaroh, 2015). Another study at high schools in Surakarta showed that knowledge was related to premarital sexual behavior $(p$-value $=0.022<0.05) \quad($ Darmasih, 2009) . Knowledge is the result of knowing, and this happens after people perceive a particular object (Notoatmodjo, 2010).

The formation of knowledge itself is 
Table 3. Results of Chi Square Analysis between Knowledge, Attitudes, Self-Confidence, Information Sources, Family Roles, Teacher Roles and Peer Role Roles.

\begin{tabular}{|c|c|c|c|c|c|c|c|c|}
\hline \multirow[t]{3}{*}{ No } & \multirow[t]{3}{*}{ Independent variables } & \multicolumn{4}{|c|}{ Premarital sex behavior } & \multirow[t]{3}{*}{$\mathrm{RP}$} & \multirow[t]{3}{*}{$\mathrm{CI}$} & \multirow[t]{3}{*}{ P-Value } \\
\hline & & \multicolumn{2}{|c|}{ Positive } & \multicolumn{2}{|c|}{ Negative } & & & \\
\hline & & $\mathrm{n}$ & $\%$ & $\mathrm{n}$ & $\%$ & & & \\
\hline \multirow[t]{3}{*}{1} & Knowledge & & & & & & & \\
\hline & Low & 57 & 64 & 94 & 24 & 3.893 & $2.642-5.737$ & 0.000 \\
\hline & High & 32 & 36 & 296 & 76 & & & \\
\hline \multirow[t]{3}{*}{2} & Attitude & & & & & & & \\
\hline & Negative & 78 & 87.6 & 160 & 40.8 & 7.240 & $3.953-13.264$ & 0.000 \\
\hline & Positive & 11 & 12.4 & 232 & 59.2 & & & \\
\hline \multirow[t]{3}{*}{3} & Self esteem & & & & & & & \\
\hline & Low & 56 & 62.9 & 101 & 25.8 & 3.502 & $2.382-5.150$ & 0.000 \\
\hline & High & 33 & 37.1 & 291 & 74.2 & & & \\
\hline \multirow[t]{4}{*}{4} & Information Source & & & & & & & \\
\hline & Low & 61 & 68.5 & 192 & 49 & - & - & 0.003 \\
\hline & Moderate & 12 & 13.5 & 107 & 27.3 & & & \\
\hline & High & 16 & 18 & 93 & 23.7 & & & \\
\hline \multirow[t]{3}{*}{5} & Family role & & & & & & & \\
\hline & Low & 24 & 27 & 125 & 31.9 & 0.823 & $0.537-1.260$ & 1.436 \\
\hline & High & 65 & 73 & 267 & 68.1 & & & \\
\hline \multirow[t]{3}{*}{6} & Teacher role & & & & & & & \\
\hline & Low & 21 & 23.6 & 57 & 14.5 & 1.596 & $1.043-2.441$ & 0.053 \\
\hline & High & 68 & 76.4 & 335 & 81.5 & & & \\
\hline \multirow[t]{3}{*}{7} & Peer role & & & & & & & \\
\hline & High & 83 & 93.3 & 178 & 45.4 & 11.660 & $5.193-26.183$ & 0.000 \\
\hline & Low & 6 & 6.7 & 214 & 54.6 & & & \\
\hline Tota & & 89 & 100 & 392 & 100 & & & \\
\hline
\end{tabular}

Source: Primary Data 2017

influenced by internal factors, namely the way an individual responds to that knowledge and external stimulus is a way to change that knowledge even better (Darmasih, 2009). The higher the reproductive health knowledge adolescents have, the lower their premarital sexual behavior, on the contrary the lower their reproductive health knowledge the adolescents have, the higher their premarital sexual behavior. This result is supported by a survey conducted by WHO in several countries which shows that good and correct information can reduce reproductive problems in adolescents. Thus, it can be said that the higher the level of adolescent knowledge, the better the behavior, because knowledge or cognitive is a domain that is very important for the formation of one's actions (overt behavior). Behavior that is based on knowledge will be more lasting than behavior that is not based on knowledge. Many adolescents know about sex, but cultural factors that forbid talking about sexuality in public because it is considered taboo, will eventually lead to incomplete adolescent knowledge about sex where adolescents only know how to have sex but do not know the consequences of sex behavior.

The bivariate test results between attitudes and premarital sexual behavior showed $p$-value $=0.000$, which means there was a relationship between attitudes and premarital sexual behavior. The results of the Ratio Prevalence 
(RP) were more than 1 (7.240), which means that the prevalence of premarital sexual behavior in adolescents who have a negative attitude towards premarital sexual behavior was 7.240 times greater than the prevalence of premarital sexual behavior in adolescents who have attitudes positive. Attitude is a risk factor for premarital sexual behavior.

These results are in accordance with the results of previous studies that stated there was a significant relationship between attitudes toward premarital sexual behavior of adolescents $(p=0.000)$ (Umaroh, 2015). The results of other studies obtained $p$-value $=0.047$ $(p<0.05)$ which means there is a difference in the proportion between respondents who have negative and positive attitude or there is a significant relationship between attitudes and premarital sexual behavior. In addition there is a relationship between attitudes toward sexual behavior with the intention to have sexual intercourse. This means that the more positive the attitude of adolescents to sexual behavior, the greater the intensity of sexual behavior, while adolescents who have a negative attitude towards sexual behavior will be less intense in their intention to engage in sexual behavior.

Attitude is a factor which may affect individual specific tendency, to react in a form of certain behavior, according to the attitude object being perceived through experiences in his/her life (Sinaga, 2013). The more positive (permissive) the attitude on adolescents' sexual behavior, the higher predisposition of the adolescents to have a further physical intercourse with the partner. Attitude is an internal (closed) reaction or response of a person toward stimulus or object. Attitude may be positive or negative (Ayu and Kurniawati, 2017). Adolescents are entities entering adulthood phase. In that age, biological drive has been amplifying. In that age as well, adolescents stay to wait until marriage age. Of course, this strongly affects their sexual behavior. Although their attitude is considered negative on the premarital sex behavior, they may act a positive behavior. Adolescents which postponed their marriage were unable to repress their biological drives (Lestari, 2014). Attitude was a predisposition generating behavior in accordance with the attitude. Attitude raised from the early perceived knowledge which considered positive (good value) or negative (bad value), then it became internalized (Dalimunthe, 2015).

Bivariate analysis between selfconfidence and premarital sexual behavior resulted $p$-value of 0.000 , meaning that there was a correlation between these two variables. The value of Ratio Prevalence (RP) was more than 1 , that was 3.502 , meaning that the prevalence of premarital sexual behavior of the adolescents with low self-confidence was 3.502 times greater than the prevalence of premarital sexual behavior in adolescents with higher selfconfidence. (Low) self-esteem was a risk factor for premarital sexual behavior.

This result was consistent with the result of study performed in MAN (High School) 1 Samarinda which stated that self-esteem significantly correlated to premarital sexual behavior $(p=0,044)$ (Khairunnisa, 2013). This result suggested that the higher self-control in the adolescents, the lower incidence of premarital sexual behavior among them. Oppositely, the lower self-control in the adolescents, the higher incidence of premarital sexual behavior.

Individual having self-control will be able to avoid any negative behaviors. Self -control was defined as capacity of individual to resist inner drive to behave negatively contradictive to social norms. Such negative behavior not suitable to social norms included addiction on drugs and other substances, cigarettes, alcohol, as well as premarital sexual behavior. Premarital sexual behavior in adolescents would result a negative impact psychologically such as shame, physiologically such as extramarital pregnancy, socially such as rejection from society, and physically such as HIV/AIDS infection (Sarwono, 2010). The theory of self-esteem together with other essential aspects in personality was a means of self-control in human behavior. Self-esteem alone was inconsistent to prevent all risks because self-esteem was likely a result and was not a successful behavior.

The result of bivariate test between source of information and premarital sexual behavior showed $p$-value of 0.003 , suggesting a correlation between the source of information 
and premarital sexual behavior. Media might play role in changing individual behavior. For an example, adolescents who watched teengenre movies containing western culture, through observation, they viewed that sex is fun and acceptable in society. Adolescents tended to adopt that value, sometimes with no consideration of the difference between western and eastern culture, value, and norms in two different societies. This exposure allowed individual to be aroused to try premarital sexual behavior.

This result was overall consistent with the result of study conducted on students in Jakarta's Junior High School which stated a correlation between source of information and adolescents' premarital sexual behavior $(p=0.000)$ (Fresillia, 2013). Another study on student in Academy of Health in Lebak Regency concluded that students exposed to pornography from media tended to perform high risk sexual behavior compared to students less exposed ( $p$-value $=$ 0.004) (Sinaga, 2013). The more advance the media and communication device resulted in an uncontrollable information influx (Fresillia, 2013). Predisposition of curiosity in adolescents including on sexual knowledge increased as well because of the source of information was accessible easily from peers, magazines, VCD, and internet access, whereas the input of that information might not always be true and quality, instead of vulgar and gross, therefore the result was that adolescents try to practice that wrong sexuality behavior (Zainafree, 2015). Based on theory of information, it showed that one of factors affecting knowledge was the information media. Information obtained from formal or non-formal education might result in immediate impact therefore causing change or improvement of knowledge (Hillinski and Freiburger, 2018).

Bivariate analysis between role of family and premarital sexual behavior showed $p$-value of 1.436, which means there was no correlation between these two variables. The result of Ratio Prevalence (RP) was 0.823. Value of RP $<1$ suggested that the role of family was not actually a protective factor in premarital sexual behavior.

This result agreed with previous result of study which revealed that there was no correlation between the role of parents and premarital sexual behavior in their adolescents with $p$-value of $0.720(p>0.05)$ in which the study resulted that $7 \%$ of respondent's parents supported premarital sexual behavior, compared to $93 \%$ of parents which disagreed with premarital sexual behavior (Lestari, 2014). Several hypotheses suggested that first sexual intercourse in adolescents correlated to family situation not allowed educating their children properly in facing adolescent phase. Adolescent phase is the stage where physical and psychological changes occur, therefore the role of parents is crucial to guide adolescent's development (Safitri, 2015). In a developmental stage of adolescents, parents needed to provide information about physical changes to minimize fear/anxiety to help adolescents in facing puberty stage and to set restriction based on value and norms between good and bad sexual behavior as well. Adolescents might share their feelings with parents. If no serious response provided, it might create communication gap and mistrust to the parents. Unsupportive parents were those who did not support the occurrence of premarital sexual behavior in adolescent which taught their children about reproductive health and became a role model in implementing good attitude and behavior for their children in daily living (Gustina, 2017). Family is the first and the main environment for children development, the disharmony between children and parents resulted in pathologic condition in that family. This contributes to the reinforcing factor in the development of deviant sexual behavior tending to risk of HIV/ AIDS transmission (Rokhmah, 2015).

First sexual intercourse in adolescent was one of impacts of family condition unable to properly prepare their children to enter adolescent phase. Parents played important role in giving guidance and suggestion to children in order to build attitude of discipline and responsibility for the children in following social and religious norms. Family was the first social exposure contributing strongly in adolescents' growth and development (Soetijiningsih, 2010). Ideally, adolescent development would be optimal if they lived in harmonious families, therefore adolescents could fulfill their needs and follow their parents as a good role models 
(Zefannya, Tinuk, and Bagoes, 2016).

Bivariate analysis between the role of teachers and premarital sexual behavior resulted $p$-value of 0.053 , which suggested no correlation between these two variables. But, the result of Ratio Prevalence (RP) value was 1.596, which suggested that prevalence of teacher who less played the role in lowering adolescents' premarital sexual behavior development consisted risk of 1.596 times higher than the teachers actively playing the role. Thus, the role of teacher was risk factor for premarital sexual behavior.

Study on sexual behavior in Senior High School students in area of Puskesmas (Center for Public Health) Halmahera of Semarang city showed that teachers contributed in providing reproductive health for $98 \%$. This result described that the role of teacher was considerable (Lestari, 2014). Another study also stated that teachers as educator played vital role in sexual education at school such as prevention of free sex behavior. School was a place contributing in providing sex education for adolescents in Indonesia. Teachers had a duty to create a learning environment to be conducive, comfortable, in order to create students with character. Hence, sex education was favorable to be included in the effort to create students with character capable of preventing free sex and other deviant behaviors for their selves and others as well. Different study showed a correlation between the role of school and premarital sexual behavior which was significant statistically $(p<0.001)$ (Qomarasari, 2015).

Teachers played a central role either as planners, executors, or evaluators of learning. It suggested that teachers' capability in creating quality learning process possessed a key for the successful education results generally. Quality of learning depended on the teachers' capability, particularly in providing ease in learning for the students effectively, and efficiently. The role and function of teachers to understand the students' development in preventing free sex behavior was crucial because an adolescent would experience many changes sexually, either on physical aspects, psyche, or daily behavior. An educator needed to intensively and responsively instill the virtuous moral value to the students, because teacher played a role in delivering explanation of negative impacts resulted from deviant behavior for example sexually transmitted disease and intrusion on their psychological state (Qomarasari, 2015).

Bivariate analysis between the role of peers and premarital sexual behavior resulted $p$-value of 0.000 , suggesting a correlation between the role of peers and premarital sexual behavior. Result of Ratio Prevalence (RP) value was 11.660. This suggested that prevalence of peers' impact in performing premarital sexual behavior consisted risk of 11.660 times higher than the less played role peers. This result considered the role of peers as a risk factor.

This result was consistent with another study that showed correlation between the role of peers and premarital sexual behavior with $p$-value of $0.001(\mathrm{p}<0.05)$. Role of college peers supporting premarital sexual behavior was $83.4 \%$ (Lestari \& Ika, 2014). Another study showed that $34.17 \%$ of female adolescents in Purwokerto Regency experienced sexual violence by being kissed forcibly (Ayu, 2012). Influence of peers consuming substance also contributed in sexual behavior in India (Wilkerson et al., 2018). Important finding in the study was that peers contributed in building adolescents' sexual behavior, but the impact was greater in male adolescents. Beside of peers' role, this study resulted that alcohol consumption and drugs abuse contributed in the increased incidence of premarital sexual behavior in adolescents. While, communication with parents, media exposure, higher education level were protective factors in female adolescents to undo premarital sexual behavior. Several studies showed that peers contributed in the increased contra-healthy behavior such as smoking and alcohol consumption. Adolescents having peers that had experienced premarital sexual intercourse was more likely to imitate the risky sexual behavior. The role of male peers was greater than of female peers, it was possible due to the difference of social norms believed by male and female adolescents. (Bongardt, 2015)

Sexual information from peers with invalidated truth might affect adolescents negatively. The peers generally obtained information just from impression form mass media such as: movies, VCD, television, and self- 
experience. Such information and experience were directly shared to friends without filtering first which were true and appropriate. Certainly those might affect the knowledge and attitude of adolescents about sexual acts possibly to do with their partners (Dewi, 2012).

\section{Conclusion}

According to the discussion, researchers concluded that there are 5 of 7 independent variables studied that correlate significantly to premarital sexual behavior in adolescent students in Yogyakarta city. The fifth variables include knowledge, attitude, self-esteem, source of information, and role of peers. Role of family or teachers is non-correlating factor to premarital sexual behavior in adolescent students in Yogyakarta.

\section{References}

Ayu, S.M. (2012). Kekerasan Dalam Pacaran Dan Kecemasan Remaja Putri Di Kabupaten Purworejo. Jurnal KesMas, 1(6), 61-74.

Ayu. , S.M., Kurniawati Tri. (2017). Hubungan Tingkat Pengetahuan Remaja Putri Tentang Aborsi Dengan Sikap Remaja Terhadap Aborsi Di Man 2 Kediri Jawa Timur. Unnes Journal of Public Health, 6(2), 2-5.

Azinar, M. (2013). Perilaku Seksual Pranikah. Jurnal Kesehatan Masyarakat, 8(2), 153-160.

Badan Pusat Statistik. (2005). Sensus Penduduk Tahun 2000.

Bendas, Hummel T, Croy I. (2018). Olfactory Function Relates to Sexual Experience in Adults. Arch Sex Behav, 5(47), 1333-1339.

BKKBN. (2011). Policy Brief Kajian Profil Penduduk Remaja (10-24 tahun): Ada Apa Dengan Remaja?

Dalimunthe, Candra Rukmana dan Kristina Nadeak. (2012). Tingkat Pengetahuan Pelajar SMA Harapan-1 Medan tentang Seks Bebas dengan Risiko HIV/AIDS. Ejournal Fakultas Kedokteran USU. 1(1) : 1-4.

Darmasih, R. (2009).Faktor-faktor yang Mempengaruhi Seks Pra Nikah. Skripsi. Universitas Muhammadiyah Surakarta.

Dewi, P.A. (2012). Hubungan Karakteristik Remaja, Peran Teman Sebaya, dan Paparan Pornografi Dengan Perilaku Seksual Remaja di Kelurahan Pasir Gunung Selatan Depok. Thesis. Universitas Indonesia

Fresillia, Y. (2013). Perilaku Seks Pranikah Remaja pada Siswa/i SMP Jakarta. Jurnal Ilmiah Kesehatan, 5(2), 17-20.

Gustina, E. (2017). Komunikasi Orangtua-Remaja Dan Pendidikan Orangtua Dengan Perilaku
Seksual Berisiko Pada Remaja. Unnes Journal of Public Health, 2(6), 131-136.

Handayani, O. W. K., Wiranti, I., Raharjo, B. B., \& Nugroho, E. (2019). The Reproduction Health Behavior of High School Teenagers in Semarang, Indonesia. The Open Public Health Journal, 12(1).

Harries, M., Paglia, H., Redden, S., \& Grant, J. (2018). Age at first sexual activity: Clinical and cognitive associations. Ann Clin Psychiatry, 2(30), 102-112. Retrieved from https://www. ncbi.nlm.nih.gov/pubmed/29697711

Hillinski, R. C., \& Freiburger, T. (2018). Sexual Violence Among Male Inmates. JInterpers Violence. https://doi. org/10.1177/0886260518770190

Khairunnisa, A. (2013). Hubungan Antara Religiusitas dan Kontrol Diri dengan Perilaku Seksual Pranikah Remaja di MAN 1 Samarinda, Ejournal Psikologi, 2013.

Lestari, A., \& Ika. (2014). Faktor-Faktor yang Berpengaruh dengan Perilaku Seks Pranikah pada Mahasiswa. Unnes Journal of Public Health, 3(4), 27-38.

Notoatmodjo, S. (2010). Promosi Kesehatan Teori dan Aplikasi.Jakarta: Rineka Cipta.

Nugroho, E., Shaluhiyah, Z., Purnami, C. T., \& Kristawansari. (2017). Counseling Model Development Based On Analysis Of Unwanted, Jurnal Kesehatan Masyarakat 13(1), 137-144.

Qomarasari, D. (2015). Hubungan Antara Peran Keluarga, Sekolah, Teman Sebaya, Pendapatan Keluarga, Media Informasi dan Norma Agama Dengan Perilaku SEksual Remaja di Surakarta.Thesis. Universitas Negeri Semarang.

Rokhmah, D. (2015). Pola Asuh dan Pembentukan Perilaku Seksual Berisiko Terhadap HIV/ AIDS Pada waria. Jurnal Kesehatan Masyaakat, 11(1), 125-134.

Safitri, O. (2015). Faktor-faktor yang Mempengaruhi Perilaku Seksual Pranikah Siswa SMA Negeri 1 Pesawaran Tahun 2015. Jurnal Universitas Malahayati, Bandar Lampung.

Sinaga S,E,N. (2013). Faktor -faktor yang mempengaruhi perilaku seks pranikah pada mahasiswa akademi kesehatan $\mathrm{x}$ di kabupaten lebak. Arc. Com. Health, 2(1), 50-55.

Sarwono, S. W. (2010). Psikologi Remaja. Yogyakarta: Raja Grafindo Persada

Soetijiningsih. (2010). Tumbuh Kembang Remaja dan Permasalahannya. Sagung Seto.

Suparmi, \& Isfandari, S. (2016). Peran Teman Sebaya terhadap Perilaku Seksual Pranikah pada Remaja Laki-Laki dan Perempuan di 
Indonesia, Buletin Penelitian Kesehatan. Vol. 44 (2).139-146.

Umaroh, A.Y. (2015). Hubungan antara faktor Internal dan Faktor Eksternal Dengan Perilaku Seksual Pranikah Remaja di Indonesia (Analisis Data SDKI 2012) ). Jurnal Kesehatan Masyarakat Andalas. 10(1), 65-75.

Van de Bongardt D, Reitz E, Sandfort T, Dekovic M. (2015). Meta-Analysis of the Relations Between Three Types of Peer Norms and Adolescent Sexual Behavior. Personality and social psychology review : an official. Journal of the Society for Personality and Social Psychology, 19(3), 203.

Wilkerson JM, Di Paola A, Rawat S, Patankar P, Rosser BRS, Ekstrand ML. (2018). Substance
Use, Mental Health, HIV Testing, and Sexual Risk Behavior Among Men Who Have Sex With Men in the State of Maharashtra, India. AIDS Educ Prev, 30(2), 96-107.

Zainafree, I. (2015). Perilaku Seksual dan Implikasinya terhadap layanan kesehatan Reproduksi Remaja di Lingkungan Kampus (Studi kasus pada mahasiswa Universitas Negeri Semarang). Unnes Journal of Public Health, 4(3), 1-7.

Zefannya, M. Tinuk, I., \& Bagoes, I. (2016). Faktor Yang Berhubungan Dengan Praktik Seks Pra Nikah Dikalangan Anak Jalanan Kota Semarang. Ejournal Jurnal Kesehatan Masyarakat, 3(4), 1029-1035. 